\section{Study On Physicochemical Parameters And Distribution of Phytoplankton In Kuantan Estuary, Pahang}

Jalal, K.C.A ${ }^{1}$., Akbar John, B $^{2}$. Hassan I. Sheikh ${ }^{2}$, Shahbudin, $\mathbf{S}^{\mathbf{1}}$. 1Nor Hafiza, Y.A.A.

${ }^{1}$ Department of Marine Science, ${ }^{2}$ INOCEM Research Station (IRS), International Islamic University Malaysia (IIUM), Kuantan, Pahang,

This is an open access article distributed under the Creative Commons Attribution License, which permits unrestricted use, distribution, and reproduction in any medium, provided the original work is properly cited.

\section{ARTICLE DETAILS}

\section{Article history:}

Received 27 September 2016 Accepted 13 December 2016 Available online 10 January 2017

Keywords:

physicochemical parameters, Kuantan estuary, phytoplankton

\begin{abstract}
A study on physicochemical parameters and distribution of phytoplankton communities was carried out at Kuantan estuary, Pahang, Malaysia. The study was carried out in September, 2011 and November, 2011 to determine the spatial distribution of phytoplankton from three different stations during the pre-monsoon and monsoon seasons. The phytoplankton and water quality were analyzed using standard method outlines by APHA, 1998. The temperature recorded was between $27.29 \mathrm{oC}$ to $29.33 \mathrm{oC}$, $\mathrm{pH}$ was from 6.96 to 8.24 , conductivity range from $33.50 \mathrm{mS} / \mathrm{cm}$ to $47.85 \mathrm{mS} / \mathrm{cm}$, dissolved oxygen ranged was from $4.25 \mathrm{mg} / \mathrm{L}$ to $5.84 \mathrm{mg} / \mathrm{L}$, biochemical oxygen demand was from $3.37 \mathrm{mg} / \mathrm{L}$ to $1.60 \mathrm{mg} / \mathrm{L}$, salinity range from $21.01 \mathrm{ppt}$ to $30.72 \mathrm{ppt}$, total dissolved solids range from $21.80 \mathrm{~g} / \mathrm{L}$ to $31.60 \mathrm{~g} / \mathrm{L}$ and total suspended solids range from 0.024 to 0.044 . The nitrite concentration was range from $0.078 \mathrm{mg} / \mathrm{L}$ to $0.088 \mathrm{mg} / \mathrm{L}$ during monsoon while in the pre-monsoon seasons the range was from $0.018 \mathrm{mg} / \mathrm{L}$ to $0.025 \mathrm{mg} / \mathrm{L}$. Similarly, ammonium concentration was from $0.3056 \mathrm{mg} / \mathrm{L}$ to $0.0670 \mathrm{mg} / \mathrm{L}$. The phosphorus content was range from $0.0110 \mathrm{mg} / \mathrm{L}$ to $0.0897 \mathrm{mg} / \mathrm{L}$. The pre-monsoon season phytoplankton (1466 Cells/L) was found to be higher than the monsoon season phytoplankton (644 Cells/L).
\end{abstract}

\section{INTRODUCTION}

Water quality refers to measurements of physical, chemical and biological properties of water that affect a wide range of ecological processes within the estuary. Variations in concentrations of chemical constituents as for example, nutrient concentrations and the magnitude of physical parameters such as temperature are affected both by natural processes and by human activity within the surrounding watershed and air shed. Activities from agricultural runoff, residential and municipal sewage effluents and industrial waste are the ultimate sources of contamination that contribute to poor water quality [1]. Hence, Physico-chemical parameter is an essential knowledge necessity in the sustainable process of development and for aquatic management [2].

Water is considered polluted if a substance or condition is present that renders the water useless for a particular purposes. Contamination in water with substances that can promote algal growth that possibly lead to eutrophication is one of the major problem causes degradation to water body. For example, phytoplankton is the basic units in the aquatic ecosystems and hence changes in phytoplanktonic population have a direct link with the change of water quality in any aquatic medium [3]. Moreover, contaminated water also contributes to the imbalance and disruption of the aquatic ecosystems as well as the biological status of aquatic communities. Reliable monitoring data in long-term, short-term and continuous monitoring conditions are the basis for assessing pollution in the aquatic environment. Monitoring is defined by the International Organization for Standardization (ISO) as: "the programmed process of sampling, measurement and subsequent recording or signaling or both, of various water characteristics, often with the aim of assessing conformity to specified objectives" [4]. Monitoring and analyzing water quality is one of the important initiatives in maintaining and assessing water quality. Therefore, this study is conducted to establish data and information on the Kuantan estuary focusing on physico-chemical parameters and distribution of phytoplankton as indicators of water quality. An analysis on physicochemical parameters in examining the water quality comprise of $\mathrm{pH}$, temperature, conductivity, dissolved oxygen (DO), biochemical oxygen demand (BOD), total dissolved solids (TDS), salinity and total suspended solids (TSS).

This study has been carried out in Kuantan estuary based on its adverse effects due to the deterioration of the surrounding environment. An earlier study by Yusoff et al. [5] and Zaleha et al. [6] illustrated that human activity in Kuantan estuary have the potential to change the water quality and impact the local biota as a result of its environmental impact. Thus, the aim of this study is to preserve the good water quality for the estuary and the related ecosystem.

\subsection{MATERIALS AND METHODS}

2.1 Study Area

Present study was carried out during the high tides and low tides at Kuantan estuarine system in Kuantan, Pahang, Malaysia (Fig 1). Kuantan estuary is believed to hold the richness of natural productive ecosystems in Malaysia and thus enhance the potential value of aquaculture of brackish water fish and shrimp [7]. Therefore, this study area was chosen because it is now threatened by several kinds of pollutions resulted from the rapid development progress.

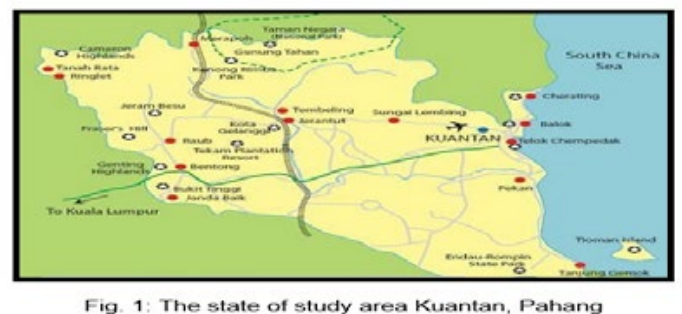

2.1.1 Sampling Sites Locations

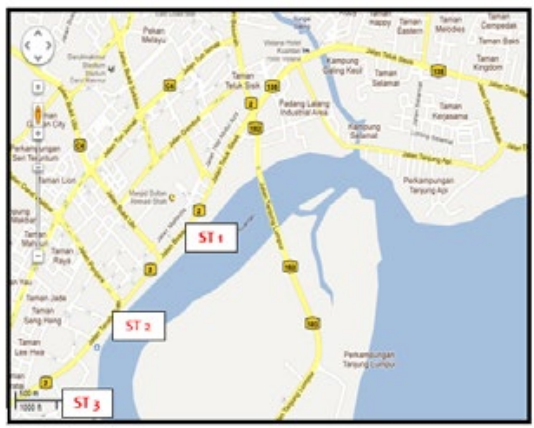

Fig 2 Location of the sampling siles at Kuantan estuary

The map above shows the sampling site locations at Kuantan River, Pahang (Fig 2). There were three different stations chosen during the field study. The stations were chosen based on land marked indicators such as ST 1 is located near the Tanjung Lumpur bridge, ST 2 is located in front of Hospital Tengku Ampuan Afzan (HTAA) while last station ST 3 is located near fish ball factory. 


\subsection{Sampling}

The study was conducted during the high tides and low tides in the estuary to measure the physico-chemical parameters towards the distribution of phytoplankton at three different stations. The phytoplankton and water quality were analyzed by using standard method outlines by [8].

\subsection{Water Quality analysis}

\subsubsection{Physico-chemical parameters measurements}

The study on physico-chemical parameters of Kuantan estuarine system was carried out in-situ by using YSI Multi-probe system (MPS) Model 556.

\subsubsection{Nutrients analysis}

The study on nutrients availability was conducted to measure the nutrients concentration in the water stream. Van Dorn water sampler was used to collect water samples. During sampling, water was collected at the surface layers of each station.

The analysis of ammonium was run in the laboratory following Parsons et al., [9] method. Ammonium was analyzed as soon as possible and should not exceed 24 hour from sampling time. The water samples were filtered with a $0.45 \mu \mathrm{m}$ Millipore. For the preservation purposes, water samples were added with $1 \mathrm{~mL}$ of hydrochloric acid and then kept in the refrigerator at $-20 \mathrm{oC}$ until further use for the analysis. NO2-, P043-wereanalyzed using standard procedures [8].

\subsubsection{Phytoplankton Analysis}

In the laboratory, the water samples were allowed to stand for a minimum of 24 hour before removing the supernatant. The supernatant was removed carefully until a $50 \mathrm{ml}$ concentrated sample left. There were about $1 \mathrm{ml}$ of sub sample was collected from it and transferred into a Sedgwick-Rafter counting chamber using a pipette. Identification and calculation was carried out with the microscope under the $10 \mathrm{X}$ and $40 \mathrm{X}$ magnifications. Phytoplankton genera were identified with the aid of the phytoplankton identification manuals of Dodge [10]. Based on the data obtained, the result was expressed as cells/L.

A One-Way Analysis of Variance (ANOVA) is used in order to test the equality of three or more means at one time by using variances [11]. A value of $p<0.05$ was considered to indicate a significant difference in all statistical analysis. The correlation analysis was performed using Pearson correlation. Correlation is significant at the 0.05 level (two-tailed). All statistical analyses were performed with SPSS 17.0 and Microsoft Office Excel 2007 Data Analysis.

4.0 RESULTS AND DISCUSSION

4.1. WATER QUALITY

4.1.1 Physicochemical Parameters

4.1.1.1 Temperature

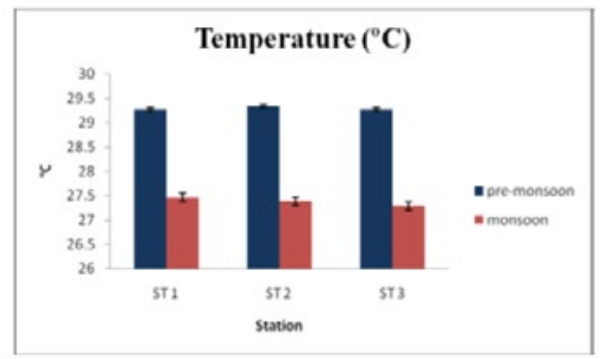

Fig. 3: Temperature at different stations for pre-monsoon and monsoon

During the pre-monsoon the highest temperature was recorded at ST 2 (29.33 oC) and lowest temperature was at ST $1(29.27$ oC). Average reading recorded during pre-monsoon was $29.29 \pm 0.03 \mathrm{oC}$. Meanwhile, for the monsoon the highest temperature was $27.46 \mathrm{oC}$ at ST 1 and the lowest was $27.29 \mathrm{oC}$ at ST 3 respectively. The average reading for monsoon was $27.38 \pm$ $0.08 \mathrm{oC}$. Overall, the statistical analysis of temperature in this study showed that there was no significant difference observed in temperature between stations since the $\mathrm{p}>0.05$.

Temperature is one of the most important parameter in determining the quality of water as differences in temperature will likely affect the ions, biochemical reactions, and concentration of dissolved oxygen, organic matter and minerals that present in water [12]. Based on the data recorded, the average temperature is higher during the pre-monsoon compared to the monsoon with the value of $29.29 \pm 0.03$ oC and $27.38 \pm 0.08$ oC respectively. This might due to the average rainfall received during both seasons where in the monsoon season there were heavy rainfall received that contributed to the lower temperature. The temperature in the pre-monsoon season was greater and closer to the optimum value for phytoplankton distribution. Therefore, the phytoplankton distribution was found to be greater in this season for each station (Fig 3).

Furthermore, scientific evidences supported that temperature should influence the metabolic and aquatic organisms activities. Mason [13] proven in his research that temperature also influenced the metabolic activities and behavior of aquatic organisms.

4.1.1.2 $\mathrm{pH}$

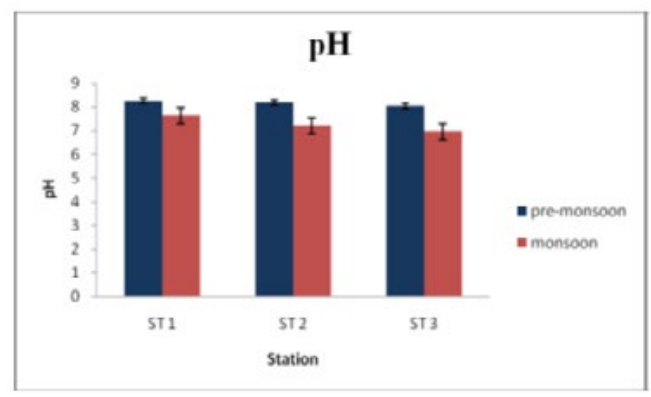

Fig. 1: pH at different stations for pre monsoon and monsoon

The highest pH value observed at ST 1 (8.24) and lowest at ST 3 (8.03) during the pre-monsoon. However, during the monsoon the maximum and minimum pH were observed at ST 1 (7.64) and ST 3 (6.96). The average value of $\mathrm{pH}$ was higher during pre-monsoon compared to monsoon, with $8.15 \pm 0.10$ and $7.27 \pm 0.34$ respectively (Fig 4 ). Generally, there was no significant difference since $\mathrm{p}>0.05$.

$\mathrm{pH}$ is a fundamental measure of acidity and alkalinity in a water body. Abel [14] stated that water with great loaded of organic pollution will have a tendency to be acidic. Obtained $\mathrm{pH}$ value indicated that the Kuantan River estuary is quite alkaline during pre-monsoon $(\mathrm{pH}=8.15 \pm 0.10)$. But the average value of $\mathrm{pH}$ in both season are still acceptable condition for growth and reproduction of aquatic species. This is supported by Malaysia National River Water Quality Standard [15] which recommended range of $\mathrm{pH}$ for growth and reproduction of aquatic species are within $\mathrm{pH} 6.5$ to 8.5 .

\subsubsection{Conductivity}

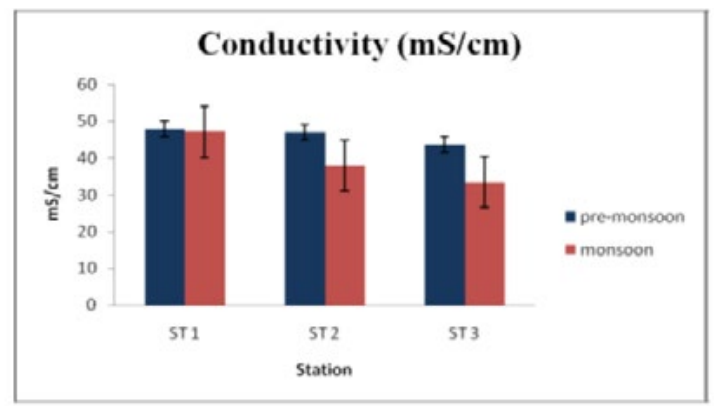

Fig. 5 . Conductivity at different stations for pre-monsoon and monsoon

The highest conductivity was recorded at ST $1(47.85 \mathrm{mS} / \mathrm{cm})$ while lowest at ST $3(43.70 \mathrm{mS} / \mathrm{cm})$ during the pre-monsoon. Meanwhile in the monsoon, the highest condunctivity was recorded at ST $1(47.10 \mathrm{mS} / \mathrm{cm})$ and the lowest at ST $3(33.50 \mathrm{mS} / \mathrm{cm})$. However, the average conductivity for premonsoon was higher $(46.15 \pm 2.18 \mathrm{mS} / \mathrm{cm})$ than the monsoon $(39.52 \pm$ $6.76 \mathrm{mS} / \mathrm{cm}$ ). There were no significant differences among the stations and between the seasons for conductivity (Fig 5).

The relative conductivity of the Kuantan estuary formed by the mixing river water with seawater has been determined. Understanding conductivity in an estuary and how it changes spatially and with depth can provide valuable insight in interpreting changes in other physical and chemical parameters [16] such as TDS and salinity.

In this study, the conductivity is measured in $\mathrm{mS} / \mathrm{cm}$. There is a large different range of conductivity between stations and seasons where the average highest value is in the pre-monsoon with $46.15 \pm 2.18$ $\mathrm{mS} / \mathrm{cm}$ and the lowest is $39.52 \pm 6.76 \mathrm{mS} / \mathrm{cm}$ during monsoon. The large differences can be explained by nature and condition of the estuary itself. There are lot of human activities executed in the studied stations. 
4.1.1.4 Dissolved Oxygen (DO)

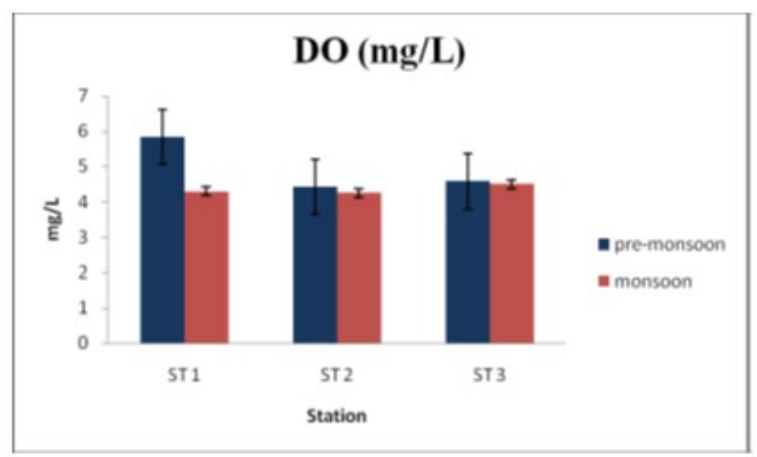

Fig. 6: DO at different stations for pre-monsoon and monsoon|

The result showed that the maximum and minimum value of DO during premonsoon was $5.84 \mathrm{mg} / \mathrm{L}$ at ST 1 and $4.42 \mathrm{mg} / \mathrm{L}$ at ST 2 correspondingly. Though during monsoon, ST $3(4.50 \mathrm{mg} / \mathrm{L})$ hold the highest value of DO while lowest value was at ST $2(4.25 \mathrm{mg} / \mathrm{L})$. In contrast to other water parameters, average of DO in pre-monsoon $(4.95 \pm 0.78 \mathrm{mg} / \mathrm{L})$ was slightly higher than DO during monsoon ( $4.35 \pm 0.13 \mathrm{mg} / \mathrm{L}$ ) (Fig 6).

DO is the measure of the amount of oxygen freely available in water. Analysis of DO is very crucial in determining water quality. According to Rozali, Abdullah and Lim [17], they elaborated that the DO concentration provides information of the biological and biochemical reaction in the water body and become the important indicator for river metabolisms. The obtained result indicate that the average DO for both pre-monsoon and monsoon are $4.95 \pm 0.78 \mathrm{mg} / \mathrm{L}$ and $4.35 \pm 0.13 \mathrm{mg} / \mathrm{L}$ respectively.

Thus, the estuary is not conducive for the aquatic organisms because the concentration of DO below $5 \mathrm{mg} / \mathrm{L}$ can cause stress to fish and can be indicative of an imbalance in the aquatic ecosystems [18].

\subsubsection{Biochemical Oxygen Demand (BOD)}

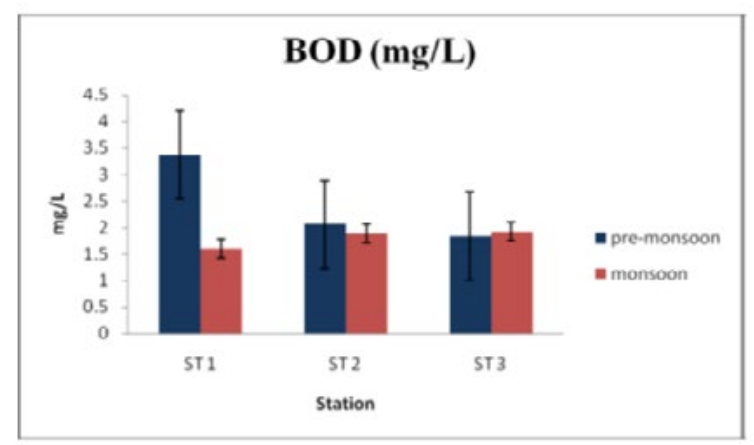

Fig. 7: $B O D$ at different stations for pre-monsoon and monsoon|

ST 1 contains the highest BOD value whereas ST 3 holds the lowest value for pre-monsoon with the value of $3.37 \mathrm{mg} / \mathrm{L}$ and $1.83 \mathrm{mg} / \mathrm{L}$ respectively. The average BOD content for the pre-monsoon was $2.42 \pm 0.83 \mathrm{mg} / \mathrm{L}$. For the monsoon, ST 3 has the maximum value of $1.92 \mathrm{mg} / \mathrm{L}$ whereas ST 1 being the lowest with $1.60 \mathrm{mg} / \mathrm{L}$. The average value of BOD in monsoon was found to be slightly lower with $1.80 \pm 0.18 \mathrm{mg} / \mathrm{L}$. There were no significant differences ( $p>0.05$ ) of BOD among the stations and seasons (Fig 7).

The BOD test is used to evaluate the amount of organic matter present in water, hence measuring the level of pollution as well. Generally, the levels of DO are inversely proportional with BOD. From this study, the average levels of BOD during pre-monsoon $(2.42 \pm 0.83 \mathrm{mg} / \mathrm{L})$ and monsoon $(1.80 \pm 0.18$ $\mathrm{mg} / \mathrm{L}$ ) is slightly lower compared to the average of DO during pre-monsoon and monsoon. These signify that there are lacks of oxygen demand by microbial activities. Thus, the BOD will tend to be lower and the DO levels tend to be higher [19].

4.1.1.6 Salinity

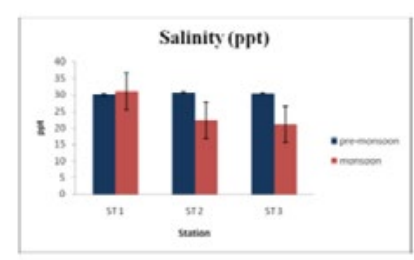

Fig. 8. Salinity at different stations for pre-monsoon and monsoon
The average of salinity in pre-monsoon was higher than in monsoon with the value of $30.37 \pm 0.34 \mathrm{ppt}$ and $24.79 \pm 5.54 \mathrm{ppt}$ in that order. During premonsoon, the highest salinity was recorded at ST 2 (30.72 ppt) while lowest at ST 1 (30.04 ppt). However, in monsoon, highest salinity was recorded at ST 1 (31.15 ppt) while lowest at ST 3 (21.01 ppt) (Fig 8).

Salinity in an estuary varies according to the location of estuary, tides and volume of freshwater that flow into an estuary $[6,20]$. The levels of salinity in an estuary is raised whenever the high tides take place as the ocean flows up the river. While, it is vice versa whenever the low tides come into contact. In the study, there are changes in salinity during pre-monsoon and monsoon. As shown in the figure 4.6, the salinity was higher during monsoon at ST 1 where at the other two station (ST 2 and ST 3) the salinity were lower during the monsoon. It might due to the salinity intrusion from the sea water. During the pre-monsoon the salinity is much greater $(30.37$ $\pm 0.34 \mathrm{ppt})$ compared to monsoon $(24.79 \pm 5.54 \mathrm{ppt})$. The distribution of phytoplankton were found greater in all three station during the premonsoon season compared to monsoon season. Thus, the increasing and decreasing in salinity will cause physiological changes which can generate the loss or gain of species. According to Kamaruzzaman et al. [21], he stated that changes in salinity can affect the biota in freshwater diversity either directly and indirectly.

\subsubsection{Total Dissolved Solids (TDS)}

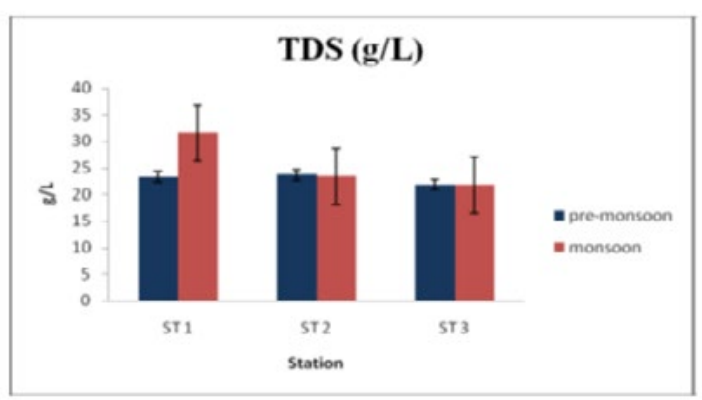

Fig 9. TDS at difterent stations tor pre-monsoon and monsoon

During pre-monsoon TDS was recorded highest at ST $2(23.68 \mathrm{~g} / \mathrm{L})$ and lowest was at ST $3(21.82 \mathrm{~g} / \mathrm{L})$ respectively. On the other hand, during monsoon ST $1(31.60 \mathrm{~g} / \mathrm{L})$ was recorded the highest reading while ST 3 hold the lowest value with $21.80 \mathrm{~g} / \mathrm{L}$ (Fig 9). The results showed that the average values of pre-monsoon was lower than monsoon with value of $22.94 \pm$ $0.98 \mathrm{~g} / \mathrm{L}$ and $25.58 \pm 5.27 \mathrm{~g} / \mathrm{L}$ in order. In spite, there were no significant differences $(p>0.05)$ among the stations and between the seasons.

TDS is the measure of the amount of material dissolved in water. This material can include carbonate, bicarbonate, chloride, sulphate, phosphate, nitrate, calcium, magnesium, sodium, organic ions and other ions. A certain level of these ions in water is necessary for aquatic life. Similar to TSS, high concentrations of TDS may also reduce water clarity, contribute to a decrease in photosynthesis, combine with toxic compounds and heavy metals and lead to an increase in water temperature. TDS is used to estimate the quality of drinking water, because it represents the amount of ions in the water.

\subsubsection{Total Suspended Solids (TSS)}

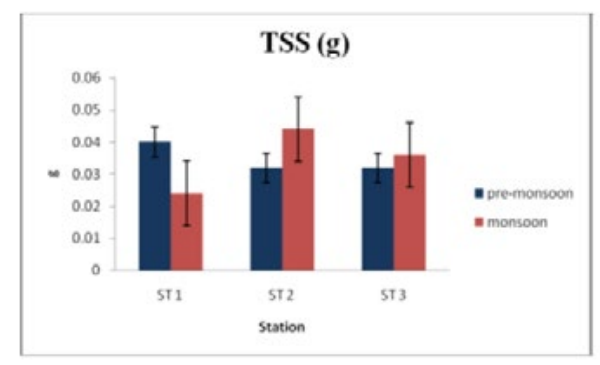

Fig. 10: TSS at different stations for pre-monsoon and monsoon

Obtained TSS value of this study was found highest in ST $2(0.044 \mathrm{~g})$ and lowest at ST $1(0.024 \mathrm{~g})$ through monsoon season. Meanwhile, during the pre-monsoon, highest TSS was recorded at ST $1(0.040 \mathrm{~g})$ while lowest was at ST $2(0.032 \mathrm{~g})$. From the result, average TSS of Kuantan estuary during pre-monsoon was equal to monsoon, with value of $0.035 \pm 0.004 \mathrm{~g}$ and $0.035 \pm 0.01$ g respectively. In short, there was no significant difference ( $p>0.05$ ) for TSS reading (Fig 10).

Total Suspended Solids (TSS) is solids in water that can be trapped by a filter. TSS can include a wide variety of material, such as silt, decaying plant and animal matter, industrial wastes, and sewage. High values of suspended 
solids can cause many problems for stream health and aquatic life. During the study, the values of TSS for both are equally the same and hold the lower reading which means the estuary are still favourable for the aquatic life.

4.1.1.9 Analysis of Nitrite

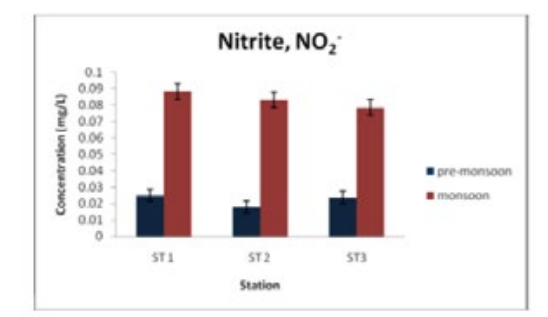

Fig. 11: Nitrite Concentration at different stations for pre-monsoon and monsoon

Nitrogen is essential for plant growth. The presence of excessive amounts of nitrogen in water body will contributed to a major problem. Nitrogen compounds may enter water body as nitrates or can be transformed to nitrites from agricultural fertilizers, sewage, legumes and drainage from livestock feeding area. Nitrates in combination with phosphate will stimulate the excessive grow of algae.

According to both season, the nitrite concentration was found to be highest during monsoon at ST 1 (average: $0.088 \mathrm{mg} / \mathrm{L}$ ), followed by ST 2 (average: $0.083 \mathrm{mg} / \mathrm{L}$ ) and lowest at ST 3 (average: $0.078 \mathrm{mg} / \mathrm{L}$ ) (Fig 11). While, the concentration of nitrite during pre-monsoon was lower at all 3 stations. The average concentration of NO2- content in monsoon was $0.083 \pm 0.005 \mathrm{mg} / \mathrm{L}$ whereas the average concentration of NO2- in pre-monsoon was $0.022 \pm$ $0.004 \mathrm{mg} / \mathrm{L}$. The nitrite concentration of the study area has no significant difference spatially as proven by statistical analysis that $p>0.05$.

Based on the average concentration of nitrite for both season $0.083 \pm$ $0.005 \mathrm{mg} / \mathrm{L}$ and $0.022 \pm 0.004 \mathrm{mg} / \mathrm{L}$, it shows that the content of nitrite in the water body were observed to be higher during the monsoon season in all three stations. This high concentration of nitrite might be from the untreated discharged effluent from domestic sewage and from the surface run-off. Similar study has been conducted by Jalal et al. [22]. He stated that the high levels of nitrite content in Kuantan estuary might due to the insufficient microbiological degradation of nutrients such as food residues. The nitrite levels found in drinking water must be less than $1 \mathrm{mg} / \mathrm{L}$. Thus, the levels of nitrite in the Kuantan estuary can be assumed as safe for consumption during pre-monsoon and monsoon where both reading does not exceed $1 \mathrm{mg} / \mathrm{L}$.

\subsubsection{Analysis of Ammonium}

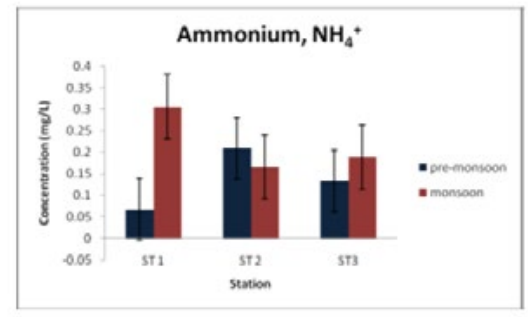

Fig. 12. Ammonium Concentration at different stations for pre-monsoon and monsoon

The ammonium concentration was found to be highest at ST 1 (average: $0.3056 \mathrm{mg} / \mathrm{L}$ ), followed by ST 3 (average: $0.1895 \mathrm{mg} / \mathrm{L}$ ) and lowest at ST 2 (average: $0.1662 \mathrm{mg} / \mathrm{L}$ ) during the monsoon. While, in the pre-monsoon the highest content of ammonium was found at ST 2 with $0.2101 \mathrm{mg} / \mathrm{L}$ and the lowest was $0.0670 \mathrm{mg} / \mathrm{L}$. The average reading for ammonium in the pre-monsoon was $0.138 \pm 0.071 \mathrm{mg} / \mathrm{L}$ whereas in the monsoon the average content of ammonium was $0.220 \pm 0.075 \mathrm{mg} / \mathrm{L}$ (Fig 12). The concentration of ammonium in the study area has no significant difference spatially and temporally as proven by statistical analysis that $p>0.05$.

Ammonium (NH4+) ion is an ionized form of nitrogen gas in water solution. There are many naturally occurring forms of nitrogen, including the nitrogen gas that comprises nearly $77 \%$ of the atmosphere. Nitrogen compounds dissolved in water are usually classified as organic or inorganic. Soluble inorganic nitrogen compounds include ammonia, nitrite, and nitrate. Nitrate is related to ammonia in that nitrifying bacteria convert ammonia to nitrate, which is less toxic to animal life.

The form of ammonium depends on $\mathrm{pH}$, where ammonium predominating when the $\mathrm{pH}$ is below 8.75 while ammonia predominating above $\mathrm{pH} 9.75$. The forms are freely inter-converted during a change in $\mathrm{pH}$.

\subsubsection{Analysis of Phosphate}

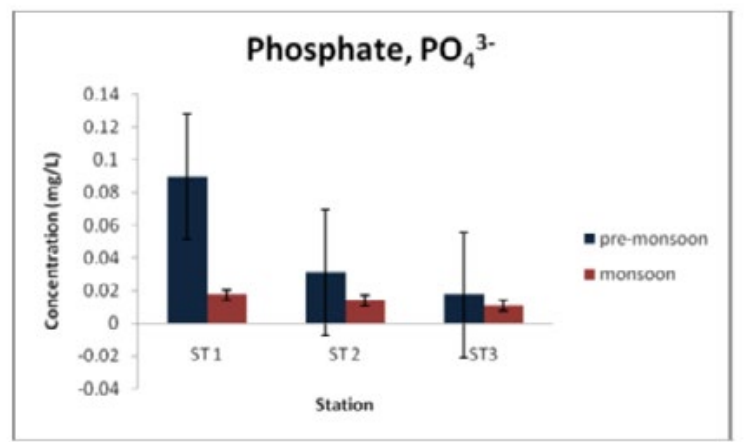

ig. 13: Phosphate Concentration at different stations for pre-monsoon and monsoon

The phosphate content was found to be highest during pre-monsoon where at ST 1 (average: $0.0897 \mathrm{mg} / \mathrm{L}$ ) and lowest at ST 3 (average: $0.0172 \mathrm{mg} / \mathrm{L}$ ). The concentration of phosphate in monsoon were lower as at ST 1 (average: $0.0173 \mathrm{mg} / \mathrm{L}$ ), ST 2 (average: $0.0137 \mathrm{mg} / \mathrm{L}$ ) and followed by ST 3 (average: $0.0110 \mathrm{mg} / \mathrm{L}$ ). Average reading for phosphate in pre-monsoon and monsoon are portrays as $0.046 \pm 0.038 \mathrm{mg} / \mathrm{L}$ and $0.014 \pm 0.003 \mathrm{mg} / \mathrm{L}$ respectively (Fig 13). There were no significant differences in phosphate concentration of Kuantan estuary both spatially and temporally with $\mathrm{p}>0.05$.

Phosphate is considered to be the most significant among other nutrients responsible for eutrophication of lakes, as it is the primary initiating factor [23]. Phosphates are not toxic to human or animals unless they are present in very high levels. Barbaro [24], mentioned that the small increases in phosphate concentrations can have substantial consequences for water quality even though that drinking water standard have not been set for phosphate. In addition, Bianchi and co-workers [25] in their study have found that excessive addition of phosphate can result in toxic algal blooms and eutrophication.

The concentration of phosphate was found greater at ST 1. This might be due to the amount of pollutant received in the mentioned station. The variety sources of pollutants include urban run-off, industrial processes wastes and detergents wastes.

The revealed results showed that the nutrient (as phosphate) in the estuary is higher during the pre-monsoon compared to monsoon. However, both season hold relatively lower concentration where the values are within limits. Rivera [26] explained that the concentration of phosphate in natural river waters is from $0 \mathrm{mg} / \mathrm{l}$ to $1 \mathrm{mg} / \mathrm{l}$.

\subsubsection{Phytoplankton Distribution}

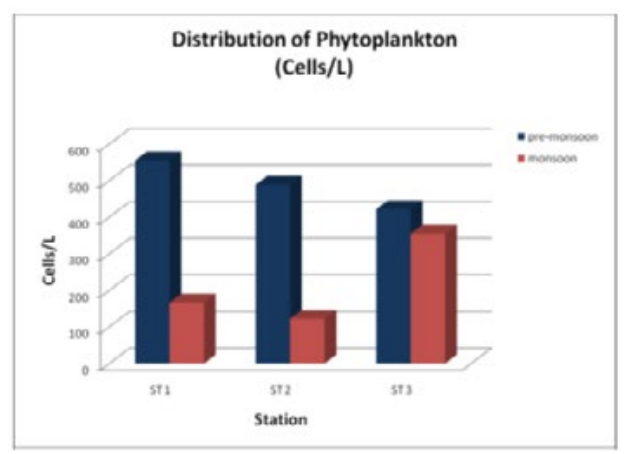

Fig. 14: Distnbution of phytoplankton at difterent for pre-monsoon and monsoon (cells/L)

Phytoplankton is an important biological indicator of water quality [27]. Phytoplankton studies and monitoring are useful for control of the physicochemical and biological conditions of water [27]. Thus, this finding was meant to evaluate the quality of water in Kuantan estuary.

Figure 14 depicts the distribution of phytoplankton according to the stations for pre-monsoon and monsoon seasons in cells/L. Based on the data obtained, pre-monsoon season recorded higher value of phytoplankton compared to the monsoon season. The total cell density counted were 1466 cells/L in the pre-monsoon season while 644 cells/L were calculated during the monsoon season. In the pre-monsoon season, ST 1 with 555 cells/L hold the maximum distribution of phytoplankton and followed by ST 2 (489 cells/L) whilst ST 3 has the minimum count of phytoplankton with 422 cells/L. In the monsoon season, ST 3 has a higher distribution of phytoplankton with 355 cells/L while the lowest was ST 2 (122 cells/L). 
Phytoplankton found from the study area can be group into diatom and dinofalgellate. Diatoms are considered the principal phytoplankton group contributing to primary production and carbon export in coastal areas. Whereas the dinoflagellates are often regarded to be an important contributor to biomass in stratified or silica limited areas and are well examined in harmful algal bloom literature. In this study, the most dominant genera of phytoplankton identified were from diatoms such as Cyclotella, Triceratium, and Actinoptychus whilst the dinoflagellates including genera Neoceratium.

\subsubsection{Pre-monsoon}

There are some factors that affecting the distribution of phytoplankton. Among the factors are light intensity, nutrients, temperature, salinity and grazing by zooplankton. Generally, phytoplankton distribution depend more on light intensity and nutrients for greater biodiversity [28, 29].

During the pre-monsoon, the distribution of phytoplankton was higher at ST 1 because the increasing supplies of phosphate as nutrient are responsible for the greater phytoplankton distribution. In other words, the nutrient levels influence total phytoplankton biomass and the distribution of the community [30].

\subsubsection{Monsoon}

During this season, due to the heavy rainfall the volumes of water in the estuary increased and thus cause the least amount of phytoplankton. The decreases in phytoplankton biomass and abundance during monsoon season was because of the high river input due to the seasonal effects of decreased temperature, decreased light availability and increased turbulence [31].

\subsubsection{Comparing the Pre-monsoon and Monsoon season}

Pre-monsoon phytoplankton was higher than in the monsoon phytoplankton. Consequently, 1466 cells/L of phytoplankton were recorded during the premonsoon compared to the monsoon season with 644 cells/L. There were differences in phytoplankton distributions between the two seasons and it could be a strong explanation that seasonal variation has an effect on the distribution of phytoplankton [6]. The results were not correlated well and have weak correlation where the distributions of phytoplankton are not linearly related to the temperature, salinity and nutrients in all three stations.

\subsection{REFERENCES}

[1] USEPA, Water Pollution Control: 25 years of Progress and Challenges for the New Millennium, Office of Wastewater, EPA 833-F-98003 (1998).

[2] M. J. Kennish, Practical Handbook of Estuarine and Marine Pollution, CRC Press, Boston, 2000.

[3] N. Dutta, J. C. Malhotra, B. B. Bose, Hydrology and seasonal fluctuation of the plankton in the Hooghly Estuary (1954), 35-47.

[4] J. Bartram, R. Balance, Water Quality Monitoring; a Practical Guide to the Design and Implementation of Freshwater Quality Studies and Monitoring Programmes. Published on behalf of United Nations Environment Programme and World Health Organization. E \& FN Spon, London, 1996.

[5] F. M. Yussof, R. P. Subasinghe, M. S. Mohd Zaki, Fisheries and aquatic environmental education in Malaysia, in: B. Japar Sidik, F. M. Yusoff, T. Petr, M. S. Mohd Zaki (Eds.), Fisheries and the Environment: Beyond 2000, Universiti Putra Malaysia, Serdang, Malaysia. 1997, p. 291-306.

[6] K. Zaleha, I. Sulong, B. Y. Kamaruzzaman, B. Mohd. Afendy, Species Composition and Abundance of Planktonic Copepods in Pahang Estuaries, Malaysia, Journal of Sustainability Science and Management. 3 (1) (2008), 11-22.

[7] K. C. A. Jalal, B. Y. Kamaruzzaman, A. Fairuz, B. Akbar, S. Shahbudin, Y. Faridah. Bacterial Communities in Kuantan Estuary of Pahang Malaysia, Journal of Applied Sciences. 10 (2009), 652-657.

[8] APHA, Standard methods for examination of water and wastewater, 17th edition. American water works association and water pollution control federal, Washington, D.C. 1998.
[9]

T. R. Parsons, Y. Maita, C. M. Lalli, A manual of chemical and biological methods for seawater analysis, Pergamom International Library, Canada. 1984, p. 173.

[10] Dodge, (1985). Marine dinoflagellates of the British Isles. London: University of London.

[11] L. L. Wong, P. T. Arumugam, Population estimation and distribution of a benthic fish, Glossogobius sp., in a tin mine lake, the Mine Resort, Malaysia, in: B. Japar Sidik, F. M. Yusoff, T. Petr, M. S. Mohd Zaki (Eds.), Fisheries and the Environment: Beyond 2000, Universiti Putra Malaysia, Serdang, Malaysia. 1997, p. 291-306.

[12] WHO, Surveillance of Drinking Water Quality. WHO Monography service No. 63 WHO, Genera. 1976.

[13] C. F. Mason, Biology of Freshwater Pollution. 3rd Edition Longman, UK, 1996.

[14] P. D. Abel, Water Pollution Biology. 2nd Edition. Taylor \& Francis, London, 1996.

[15] Malaysia National River Water Quality, Interim National River Water Quality Standards for Malaysia, Department of Environment, Malaysia, 2004.

[16] USEPA Developing and Implementing and Estuarine Water Quality Monitoring, Assessment and outreach Program, 2002.

[17] M. O. Rozali, S. Abdullah, S. H. Lim, Effect of water quality to Fish Abundance and Chlorophyll a (selected aquatic organisms) in Labu River System, Malaysia, Online Journal of Biological Sciences 1 (12) (2001), 11781182.

[18] L. C. Melanie, R. N. Jodi, Occurrence of Fecal Coliform Bacteria in Selected Streams in Wyoming, 1990-1999. Water Resources Investigation Report 00-4198. Wyoming Department of Environmental Quality and US Department of the Interior, US, 1999.

[19] N. Kamaruddin, Water Quality Analysis of Chamang River, Bentong Pahang. IIUM: The Degree of Bachelor of Biomedical Science, 2008. [20] National Ocean and Atmospheric Administration (NOAA), Global Temperature-Salinity Profile Program, 2006. Retrieved August 12, 2009. http://www.noaa.gov/ocean.html.

[21] Y. Kamaruzzaman, A. T. Law, M. H. Lukman, N. A. M. Shazili, K. Zaleha, M. Faridah, Sungai Terengganu, KUSTEM, Mengabang Telipot. 2003, p. 100.

[22] K. C. A. Jalal, M. Najiah, M. Fathiyah, Y. Kamaruzzaman, M. N. Omar, S. M. N. Amin, I. Jaswi, Bacterial pollution in molluscs arch clam, Orbiculariaorbiculata and blood cockle, Anadaragranosa of Pahang estuary, Malaysia. J. Biol. Sci. 9 (2009), 841-850.

[23] 0. K. Adeyemo, 0. A. Adedokun, R. K. Yusuf, E. A. Adeleye, Seasonal changes in physico-chemical parameters and nutrient load of river sediments in Ibadan City, Nigeria. Global NEST Journal. 10 (2008): 326-336.

[24] S. E. Barbaro, A Water Quality Monitoring Study of the Nissitissit River and Salmon Brook: Year One Data, River Academic J. 4(1) (2008), 1-20. [25] T. S. Bianchi, E. Engelhaupt, P. Westman, C. Rolff, R. Elmgren, Cyanobacterial blooms in the Baltic sea: natural or human-induced, American Society of Limnology and Oceanography 45 (2000), 716-726.

[26] C. Rivera, Performance of a passive sampler system for nitrate and phosphate monitoring, 2003.

[27] R. T. Chalinda Ariyadej, Phytoplankton diversity and its relationships to the physico-chemical environment in the Banglang Reservoir, Yala Province, Songklanakarin J. Sci. Technology , 26(5) (2004), 595-607.

[28] G. A. Riley, The plankton of estuaries, in: G. A. Lauff, (Ed.), Estuaries, AAAS Publ., Washington D.C. 1967, pp. 316-328.

[29] R. B. Williams, Annual phytoplankton production in a system of shallow temperate estuaries, in: R. H. Chabreck (Ed.), Proceedings of the Coastal Marsh, 1972.

[30] S. Watson, E. McCauley, J. A. Downing, Sigmoid relationships between phosphorus, algal biomass, and algal community structure, Canadian Journal of Fisheries and Aquatic Sciences 49 (1992), 2605-2610. [31] J. Czubakowski, Estuarine phytoplankton response to annual and manipulated river inputs, University of Wisconsin, Wisconsin, 2010. 